\title{
Aktivitas Yoghurt Kacang Komak (Lablab Purpureus (L.) Sweet) Sebagai Antihiperglikemia
}

Authors

Afiliation
Elly Wardani*, Ani Pahriyani

Farmasi, Fakultas Farmasi dan Sains, UHAMKA, Jakarta

\section{Kata Kunci \\ $\rightarrow$ Antihiperglikemia \\ O Kacang komak \\ $\rightarrow$ Yoghurt}

Diterima 20 Desember 2017

Direvisi 3 Januari 2018

Disetujui 2 Maret 2018
* Penulis Koresponding Elly Wardani

Farmasi, Fakultas Farmasi dan Sains, UHAMKA, Jakarta elly.wardanie@gmail.com

\section{ABSTRAK}

Kacang komak (Lablab purpureus (L.) Sweet) dilaporkan memiliki aktivitas sebagai antihiperglikemia. Penelitian ini merupakan penelitian pengembangan kacang komak sebagai antihiperglikemia yang dibentuk dalam sediaan yoghurt kacang komak. Sediaan yoghurt kacang komak diharapkan dapat dimanfaatkan sebagai pangan fungsional pada penderita hiperglikemia. Hewan uji hamster Syrian jantan dibagi 5 kelompok perlakuan, masing-masing terdiri dari 4 ekor hamster. Kelompok I (kontrol negatif), kelompok II (kontrol positif) diberi metformin $\mathrm{HCl}$, kelompok III, IV, dan V (kelompok uji) diberi sediaan yoghurt kacang komak dosis $2.7 \mathrm{~g} / \mathrm{kg} \mathrm{BB}, 5.4 \mathrm{~g} / \mathrm{kg}$ BB dan $10.8 \mathrm{~g} / \mathrm{kg}$ BB secara peroral. Hewan uji diberi pakan tinggi kolesterol selama 28 hari dan hari ke-21 diinduksi aloksan, kemudian diberi perlakuan sediaan uji selama 14 hari. Pengambilan darah dilakukan pada hari ke-29 dan ke-44, untuk menghitung kadar glukosa darah menggunakan fotometer klinikal. Hasil uji ANOVA satu arah menunjukkan adanya perbedaan antar kelompok perlakuan. Semua kelompok sediaan uji yoghurt kacang komak memiliki aktivitas menurunkan kadar glukosa darah terhadap hamster diabetes hiperkolesterolemia. Hasil uji Tukey penurunan kadar glukosa darah menunjukan kelompok uji sediaan yoghurt dosis $10.8 \mathrm{~g} / \mathrm{kg}$ BB sebanding dengan kelompok positif yang diberikan Metformin $\mathrm{HCl}$.

\section{PENDAHULUAN}

Yoghurt adalah susu yang dihasilkan melalui proses fermentasi menggunakan kultur bakteri asam laktat, Lactobacillus bulgaricus dan Streptococcus thermophilus (Srianta dan Trisnawati 2015). Yoghurt mempunyai beberapa manfaat yang dihasilkan oleh bakteri asam laktat yaitu dapat menghasilkan sejumlah asam organik seperti asam propionat, dan asam orotat yang berperan dalam menurunkan kadar kolesterol (Suarsana et al. 2004).

Perkembangan zaman dan teknologi yang semakin maju menuntut perubahan gaya hidup masyarakatnya temasuk dalam pola makan, yakni dari makanan yang

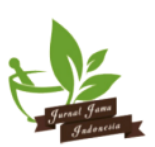


berbahan dasar karbohidrat menjadi makanan berlemak tinggi. Hal ini membawa dampak negatif terhadap naiknya prevalensi berbagai penyakit degeneratif diantaranya hiperlipidemia, hipertensi dan diabetes mellitus yang memicu terjadinya Penyakit jantung Koroner atau disingkat PJK (Suyatna 2009). Pada penderita diabetes mellitus terdapat peningkatan asam lemak bebas dalam darah dan kadar asam lemak bebas tersebut pararel dengan naik turunnya kadar glukosa darah. Peningkatan kadar asam lemak bebas dalam darah dapat mengurangi sensitivitas jaringan terhadap insulin. Hal tersebut menyatakan bahwa terdapat hubungan antara kadar lipid dengan diabetes (Ganiswara 2009). Meningkatnya penderita Diabetes Mellitus (DM) dari tahun ke tahun memerlukan suatu usaha untuk mengatasinya. Salah satu tanaman yang berkhasiat secara empiris untuk menurunkan kadar koleterol dan glukosa darah adalah kacang komak (Wardani et al. 2015).

Kacang komak mirip dengan kacang kedelai secara fisiologis dan fungsional. Khayrani (2008) membuktikan bahwa pengaruh konsentrat protein kacang komak dapat menurunkan kadar kolesterol total pada tikus diabetes yang diberi kolesterol. Pada penelitian yang dilakukan oleh Salim (2013) yoghurt kacang kedelai kuning (Glycine max (L.) Merr) dan susu kacang kedelai kuning (Nurcahyaningtyas 2012) serta ekstrak metanol kacang komak (Kante dan Reddy 2013) dapat menurunkan kadar LDL serum tikus putih jantan galur wistar hyperlipidemia. Berdasarkan latar belakang di atas, maka akan dilakukan pemberian yoghurt kacang komak pada hamster hiperkolesterolemia dan hiperglikemia penurunan kadar glukosa darah.

Tujuan dari penelitian ini untuk mengetahui aktivitas penurunan kadar kolesterol total dan glukosa darah setelah pemberian yoghurt kacang komak (Lablab purpureus (L.) Sweet) pada hamster hiperkolesterolemia dan hiperglikemia. Dengan penelitian ini diharapkan dapat memberikan manfaat yoghurt kacang komak dalam membantu proses penyembuhan diabetes komplikasi. Pasien dengan diagnosa tersebut dapat mengkonsumsi yoghurt bersamaan dengan obat-obatan yang diresepkan. Sedangkan untuk penderita prediabet konsumsi yoghurt kacang komak diharapkan mampu mengontrol kadar glukosa dan kolesterol darah sehingga penyakit tersebut tidak berkembang.

\section{METODE}

\section{Alat dan Bahan Penelitian}

Alat berupa sonde, spuit, timbangan analitik, timbangan berat badan hewan, kandang hewan uji, sentrifugator mikro, mikropipet (Eppendorf), microtube, pipa kapiler, lemari pendingin, vorteks, thermometer, spektrofotometer klinikal (varta-506), alat gelas, blender, kain saring, incubator Model 100800 (Memmert), pH meter, autoklaf Model HVE-50 (Hirayama), Laminar Air Flow, buret, waterbath dan hot plate.

Bahan berupa Kacang komak (Lablab purpureus (L.) Sweet) diperoleh dari Balittro, Bogor. Ketamin, Na$\mathrm{CMC}$, reagen kit, $\mathrm{NaOH}$, phenolphtalein, akuades dan alkohol 70\%. Pembanding yang digunakan adalah Metformin $\mathrm{HCl}$. Bakteri asam laktat yang digunakan adalah Lactobacillus bulgaricus dan Streptococcus thermophilus, susu skim $5 \%$, dan gula pasir $5 \%$. Hewan uji hamster syrian jantan (Mesocricetus auratus) usia 34 bulan dengan bobot badan $\pm 80 \mathrm{~g}$.

Untuk hewan uji menggunakan hamster dikarenakan hamster memiliki karakteristik empedu yang mirip dengan manusia dibandingkan tikus dan mencit. Hal ini berkaitan dengan penelitian yang mengkombinasikan hamster pada patologi hiperkolesterolemia dan hiperglikemia. Sedangkan untuk pembanding digunakan metformin dikarenakan obat tersebut merupakan terapi utama pada diabetes tipe 2.

\section{Persiapan Bahan Simplisia}

Kacang komak yang akan digunakan dicuci sampai bersih dengan air. Selanjutnya direndam dengan air selama 8 jam. Kemudian kacang komak dikeluarkan dari kulitnya, dan ditiriskan. Langkah selanjutnya adalah pemblenderan dengan ditambahkan air sebanyak 2 kali berat kacang komak. Hasil pemblenderan kemudian disaring untuk memisahkan antara filtrat dengan ampas. Filtrat yang diperoleh kemudian dipanaskan pada suhu $80-90^{\circ} \mathrm{C}$ selama 15 menit. Proses selanjutnya ditambahkan dengan susu skim sebanyak $5 \%$ dari volume. Susu didinginkan hingga suhu $40-45^{\circ} \mathrm{C}$ untuk kemudian diinokulasikan dengan starter bakteri asam laktat (Lactobacillus bulgaricus dan Streptococcus thermophilus 1:1) sebanyak 3\% dari jumlah volume. Dicukupkan dengan akuades sampai volumenya $200 \mathrm{ml}$, kemudian dikocok sampai homogen. Yoghurt dimasukkan ke dalam wadah kaca lalu ditutup dan diinkubasi selama 24 jam dalam

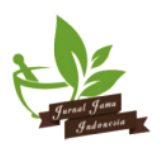


inkubator dengan suhu $37^{\circ} \mathrm{C}$. Yoghurt kemudian didinginkan dalam lemari pendingin pada suhu $4^{\circ} \mathrm{C}$ (Marcelia 2014).

\section{Rancangan Penelitian}

Rancangan penelitian menggunakan rancangan acak lengkap dengan 5 kelompok perlakuan, sehingga penentuan jumlah hamster tiap kelompok $(n=4)$ dihitung berdasarkan rumus Federer (Hanafiah 1993).

Kelompok I : Diberi pakan tinggi lemak, aloksan dan Metformin $\mathrm{HCl}$ dosis $0.065 \mathrm{~g} / \mathrm{kg}$ BB (kelompok kontrol positif).

Kelompok II : Diberi pakan tinggi lemak dan aloksan (kelompok kontrol negatif).

Kelompok III : Diberi pakan tinggi lemak, aloksan dan pemberian yoghurt kacang komak I sebanyak $1 \mathrm{ml} / 80 \mathrm{~g}$ BB (dosis $2.7 \mathrm{~g} / \mathrm{kg} \mathrm{BB}$ )

Kelompok IV : Diberi pakan tinggi lemak, aloksan dan pemberian yoghurt kacang komak II sebanyak $1 \mathrm{ml} / 80$ $\mathrm{g}$ BB (dosis $5.4 \mathrm{~g} / \mathrm{kg} \mathrm{BB}$ ).

Kelompok V : Diberi pakan tinggi lemak, aloksan dan pemberian yoghurt kacang komak III sebanyak $1 \mathrm{ml} / 80$ $\mathrm{g}$ BB (dosis $10.8 \mathrm{~g} / \mathrm{kg} \mathrm{BB}$ )

\section{Pemeriksaan Karakteristik Mutu Yoghurt Kacang Komak}

a. Uji Organoleptik

Uji organoleptik dilakukan terhadap parameter yang diujikan meliputi aroma, rasa, dan warna (Soekarto 1985).

b. Derajat Keasaman (pH)

Pengukuran derajat keasaman menggunakan $\mathrm{pH}$ meter. Sebelum digunakan alat dikalibrasi terlebih dahulu dengan menggunakan larutan buffer $\mathrm{pH} 4$ dan $\mathrm{pH}$ 7. Elektroda $\mathrm{pH}$ meter dicelupkan ke dalam sampel, kemudian dilakukan pembacaan $\mathrm{pH}$ sampel (Hidayat et al. 2013).

c. Pengukuran Asam Total

Pengukuran keasaman dilakukan dengan menghitung kadar asam setara asam laktat dengan metode titrasi asidimetri. Cara pengujiannya yaitu yoghurt yang akan diukur keasamannya diambil sampelnya sebanyak $20 \mathrm{ml}$ untuk dititrasi. Sebelum dititrasi sampel ditetesi dengan indikator fenolftalein $1 \%$ sebanyak 2 tetes. Setelah itu sampel dititrasi dengan $\mathrm{NaOH} 0.1 \mathrm{~N}$ sampai terlihat warna merah muda seulas.

Perhitungan kadar asam dilakukan dengan rumus :

$$
\text { Kadar asam }=\frac{\mathrm{V}_{1} \times \mathrm{N} \times \mathrm{B}}{\mathrm{V}_{2} \times 1000} \times 100 \%
$$

$\mathrm{V}_{1}$ adalah Volume $\mathrm{NaOH}(\mathrm{ml}), \mathrm{V}_{2}$ adalah Volume sample (ml), $\mathrm{N}$ adalah Normalitas $\mathrm{NaOH}(0,1 \mathrm{~N})$, B adalah Berat molekul asam laktat (90)(Jannah et al. 2014).

d. Pengujian Total Bakteri Asam Laktat

Perhitungan total bakteri asam laktat dilakukan dengan total bakteri asam laktat yang telah tumbuh dihitung pada media biakan Man Rogosa and Sharpe (MRS). Sampel diencerkan dengan akuades steril menggunakan perbandingan 1:9. Pengenceran dibuat hingga $10^{-1}-10^{-8}$, pada pengenceran pertama sebanyak $1 \mathrm{ml}$ sampel diencerkan ke dalam $9 \mathrm{ml}$ akuades steril. Pada pengenceran kedua dilakukan dengan mengencerkan $1 \mathrm{ml}$ diambil dari pengenceran pertama, kemudian dimasukkan ke dalam $9 \mathrm{ml}$ akuades steril. Pengenceran ketiga sampai pengenceran kedelapan dilakukan dengan cara yang sama seperti pada pengenceran sebelumnya.

Pembuatan media MRS agar dilakukan dengan cara media MRS agar sebanyak $65.13 \mathrm{~g}$ dilarutkan ke dalam $1000 \mathrm{ml}$ akuades streril, kemudian larutan MRS tersebut disterilkan dengan pada suhu $121^{\circ} \mathrm{C}$ selama 15 menit. Pencawanan diambil sebanyak $1 \mathrm{ml}$ sampel yang telah diencerkan, kemudian dimasukkan ke dalam cawan Petri steril yang berisi dengan media MRS agar setengah padat $\pm 10 \mathrm{ml}$. Pencawanan dilakukan duplo dari pengenceran $10^{-6}-10^{-8}$. Kemudian cawan Petri digerak-gerakan membentuk angka 8 , agar homogen. Setelah agar memadat, diinkubasi pada suhu $37^{\circ} \mathrm{C}$ selama 48 jam (Hidayat et al. 2013).

$$
\text { Jumlah bakteri starter }=\mathrm{n} \times \mathrm{f}
$$

dengan $\mathrm{n}$ adalah rerata koloni dari dua cawan petri dari satu pengenceran; $f$ adalah faktor pengenceran dari rerata koloni yang dipakai (SNI yoghurt 2981:2009)

\section{Pengambilan dan Pemeriksaan Serum Darah Hewan Uji}

a. Prosedur Pengambilan Darah

Darah hamster diambil dengan cara, hamster dianestesi dengan ketamin injeksi hingga tidak sadarkan diri. Darah hamster diambil dengan menusuk bagian sudut mata hamster dengan pipa kapiler, kemudian pipa kapiler diputar perlahan hingga darah mengalir. Darah ditampung pada microtube, darah diambil kira-kira $1.5 \mathrm{ml}$, kemudian disentrifugasi pada

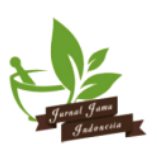


putaran 4000 rpm selama 15 menit kemudian disimpan dalam lemari pendingin (Dwitiyanti et al. 2015).

b. Pemeriksaan Kadar Glukosa darah

Serum darah diambil dengan menggunakan mikropipet sebanyak $10 \mu \mathrm{l}$ dan ditambahkan dengan reagen kit sebanyak $1000 \mu$ l. Kemudian dihomogenkan dengan menggunakan alat vorteks dan diinkubasi selama 10 menit pada suhu $25^{\circ} \mathrm{C}$, lalu dilakukan pengukuran kadar glukosa darah dengan menggunakan spektrofotometer klinikal.

\section{c. Analisis Data}

Data persentase delta penurunan kadar glukosa diuji normalitas dan homogenitas secara statistik. Selanjutnya dilakukan uji ANOVA satu arah dengan taraf signifikansi 95\%. Untuk mengetahui perbedaan antar kelompok maka dilanjutkan dengan uji Tukey (Santoso 2010).

\section{HASIL DAN PEMBAHASAN}

Fermentasi merupakan proses pengolahan pangan yang secara tradisional dengan melibatkan tiga faktor pendukung, yaitu bahan baku yang dipakai, mikroorganisme (kapang tempe), dan keadaan lingkungan tumbuh (suhu, $\mathrm{pH}$, dan kelembaban). Fermentasi bahan makanan menyebabkan perubahan fisik dan kimia yang menguntungkan seperti rasa, aroma, tekstur, dan waktu simpan (Sukaryana dkk. 2011). Fermentasi dapat meningkatkan aktivitas biologis dari suatu produk makanan dan peningkatan kandungan isoflavonoid (Keong et al. 2012).

Yoghurt dalam penelitian ini dibuat dengan 3 variasi yoghurt yang berbeda, yaitu yoghurt I (216 mg), yoghurt II (432 mg), dan yoghurt III (864 mg). Dasar pembuatan variasi tersebut adalah berdasarkan penelitian sebelumnya yang menyatakan sebanyak 4.5 g susu kacang koro pedang dapat menurunkan kadar kolesterol total sebesar $26.40 \%$ pada tikus hiperkolesterolemia (Primawestri 2015). Pemberian kacang komak tersebut kemudian dikonversikan terlebih dahulu ke hamster menjadi $5.4 \mathrm{~g} / \mathrm{kg} \mathrm{BB}$.

Yoghurt dibuat dalam satu kali pembuatan, digunakan untuk pemberian kepada hewan uji selama 14 hari agar mutu yoghurt tetap sama selama masa perlakuan. Proses pembuatan yoghurt dimulai dari perendaman kacang komak dengan air selama semalam, untuk kemudian dikelupas biji kacang dari kulitnya. Tujuan perendaman adalah agar biji kacang komak menggembung dan kulit luarnya empuk. Semakin lama waktu perendaman, biji kacang komak semakin empuk dan kulit kacang komak mudah dikelupas. Pengupasan kulit ari dilakukan agar kapang dapat tumbuh sempurna pada biji kacang komak. Pada penelitian ini pengupasan kulit ari biji kacang komak dilakukan menggunakan tangan. Pemasakan atau perebusan bertujuan untuk melunakkan biji kacang komak yang keras, sehingga memudahkan miselium kapang melakukan penetrasi dan dapat tumbuh pada permukaan kacang komak.

Uji organoleptis yoghurt kacang komak menunjukkan bahwa yoghurt berbentuk cair, memiliki bau khas yoghurt, rasanya khas asam, dan berwarna putih. Nilai pH merupakan salah satu ciri khas dari suatu produk fermentasi, terutama yoghurt. Nilai $\mathrm{pH}$ yang rendah pada produk yoghurt diakibatkan oleh karena terbentuknya asam laktat sebagai hasil degradasi laktosa oleh bakteri asam laktat. Hasil penelitian ini diperoleh nilai pH 4.33-4.40 dan menurut Standar Nasional Indonesia nilai $\mathrm{pH}$ yang baik pada yoghurt berkisar antara 4.0-4.5 (SNI 2981-2009). Nilai $\mathrm{pH}$ dapat mempengaruhi aktivitas metabolisme bakteri dan viabilitas bakteri. Aktivitas metabolisme bakteri asam laktat memiliki kaitan yang erat terhadap peningkatan asam dan penurunan $\mathrm{pH}$. Setiap organisme memiliki nilai $\mathrm{pH}$ tertentu untuk tumbuh dengan optimal, dan memiliki peran penting pada pertumbuhan dan kelangsungan hidup sel-sel mikroorganisme (Ray dan Bhunia 2008). Keasaman total dinyatakan dalam persen asam laktat. Asam laktat merupakan komponen asam terbesar yang terbentuk dari hasil fermentasi susu menjadi yoghurt. Asam laktat juga yang memberikan kontribusi besar terhadap rasa dan aroma yoghurt. Hasil penelitian ini diperoleh nilai keasaman total pada yoghurt yaitu 1.1, 0.99 dan 0.87. Menurut SNI 2981 (2009) dinyatakan bahwa kisaran nilai keasaman total yoghurt adalah $0.5-2.0 \%$. Bakteri asam laktat meupakan jenis bakteri yang memiliki peranan penting pada suatu produk susu fermentasi. Selain itu memiliki pengaruh yang nyata bagi keseimbangan mikroflora usus manusia, sehingga dapat menjaga keseimbangan dan meningkatkan kesehatan manusia. Hasil jumlah total bakteri asam laktat yoghurt kacang komak sesuai dengan Standar Nasional Indonesia, total bakteri asam laktat yang terdapat dalam yoghurt minimal adalah $1 \times 10^{7} \mathrm{CFU} / \mathrm{ml}$ (SNI yoghurt 2981-2009). Hasil karakteristik yoghurt dapat dilihat pada Tabel $1-3$. 
Tabel 1 Hasil fermentasi yoghurt kacang komak

\begin{tabular}{clcc} 
No & Jenis & $\begin{array}{c}\text { Jumlah Kacang } \\
\text { Komak }(\mathbf{g})\end{array}$ & $\begin{array}{c}\text { Volume Yoghurt } \\
(\mathbf{m l})\end{array}$ \\
\hline 1 & Yoghurt I & 15.12 & 200 \\
2 & Yoghurt II & 30.24 & 200 \\
3 & Yoghurt III & 60.48 & 200 \\
\hline
\end{tabular}

Tabel 2 Hasil uji organoleptis yoghurt kacang komak

\begin{tabular}{cccccc}
\multirow{2}{*}{ No } & \multirow{2}{*}{ Jenis } & Bentuk & Bau & Organoleptis & Wasa \\
\cline { 3 - 5 } & & Cair & Khas & Asam & Putih \\
\hline 1 & Yoghurt I & Cair & Khas & Asam & Putih \\
2 & Yoghurt II & Cair & Khas & Asam & Putih \\
3 & Yoghurt III & & & & \\
\hline
\end{tabular}

Tabel 3 Hasil uji nilai pH, keasaman total, dan total bakteri asam laktat yoghurt kacang komak

\begin{tabular}{clccc}
\hline No & Jenis & Nilai pH & Total Asam (\%) & $\begin{array}{c}\text { Total Bakteri Asam Laktat } \\
\text { (CFU/ml) }\end{array}$ \\
\hline 1 & Yoghurt I & 4.20 & 1.1 & $1.47 \times 10^{8}$ \\
2 & Yoghurt II & 4.21 & 0.99 & $1.67 \times 10^{8}$ \\
3 & Yoghurt III & 4.23 & 0.87 & $1.73 \times 10^{8}$ \\
\hline
\end{tabular}

\section{Hasil Pemeriksaan Glukosa Darah}

Uji dilakukan terhadap hewan percobaan hamster jantan yang diberi pakan tinggi kolesterol dan diinduksi aloksan monohidrat dengan dosis $17.26 \mathrm{mg} / 80 \mathrm{~g} \mathrm{BB}$, sehingga terjadi peningkatan kadar glukosa darah hamster jantan dibandingkan dengan kontrol normal. Mekanisme kerja aloksan melalui beberapa proses yang secara simultan menghasilkan efek kerusakan pada sel-sel $\beta$ pankreas. Proses yang dimaksud diantaranya pembentukan senyawa radikal bebas, terjadinya oksidasi gugus $-\mathrm{SH}$, penghambatan glukokinase serta adanya gangguan homeostatis kalsium intraseluler. Penambahan makanan tinggi kolesterol kemungkinan akan meningkatkan beberapa proses di atas.

Menurut Giri (2008) hiperkolesterolemia dapat dibuat pada beberapa hewan dengan menambahkan lemak dan kolesterol dalam makanannya yang disebut dengan induksi eksogen. Hal ini berkaitan dengan model yang digunakan pada penelitian ini yaitu hamster yang diberi pakan tinggi kolesterol dan diinduksi aloksan monohidrat. Data persentase penurunan kadar glukosa darah hamster diabetes dan hiperkolesterolemia yang diberi yoghurt kacang komak dapat dilihat pada Gambar 1.
Dilihat dari nilai presentase penurunan kadarnya, dosis yoghurt 3 merupakan dosis terbesar dalam menurunkan kadar glukosa darah dengan persentase penurunannya $47.98 \%$. Kemudian dosis 2 dengan penurunannya $39.47 \%$ dan dosis 1 dengan penurunannya $33.31 \%$. Pada kelompok kontrol negatif terjadi penurunan kadar glukosa darah sebesar $2.14 \%$. Hal ini mungkin disebabkan oleh aloksan yang digunakan bersifat reversible, sehingga menyebabkan adanya sedikit penurunan kadar glukosa darah meskipun tidak mencapai rentang kadar glukosa normal. Persentase penurunan terbesar yaitu terjadi pada kelompok kontrol positif dengan pemberian Metformin $\mathrm{HCl}$.

Hasil analisis dengan uji Tukey menunjukkan bahwa penurunan kadar glukosa darah hamster yang diberi pakan tinggi kolesterol dan diinduksi aloksan kelompok dosis 3 tidak berbeda bermakna dengan kelompok positif. Hal ini menunjukkan bahwa pemberian yoghurt kacang komak pada dosis 3 yaitu $10.8 \mathrm{~g} / \mathrm{kg}$ BB sudah mampu menurunkan kadar glukosa darah dengan persentase penurunan sebesar $47.98 \%$ yang sebanding dengan kontrol positif. Data uji statistik menunjukkan bahwa semua kelompok uji dosis 1,2,3 maupun kontrol positif berbeda bermakna dengan kontrol negatif. Hal ini menunjukan semua kelompok uji dosis 1,2 dan 3

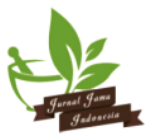




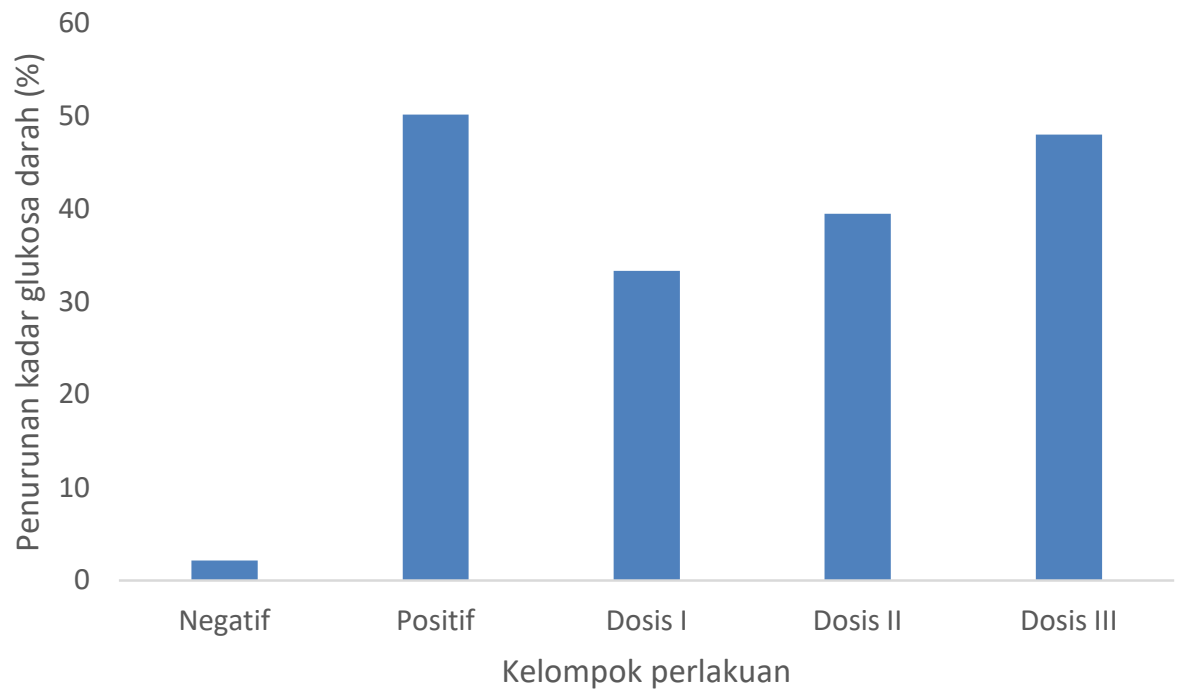

Gambar 1 Grafik Rerata Persentase Penurunan Kadar Glukosa Darah

memiliki kemampuan dalam menurunkan kadar glukosa darah pada hamster diabetes hiperkolesterolemia. Kelompok dosis 1 dan 2 berbeda bermakna dengan kontrol positif, sehingga dosis 1 dan 2 memiliki kemampuan dalam menurunkan kadar glukosa darah namun belum sebanding dengan kontrol positif.

Dari data tersebut dosis 1 sudah memberikan efek antihiperglikemia pada hamster diabetes hiperkolesterolemia, dikarenakan di dalam yoghurt terdapat senyawa bioaktif isoflavon yang secara ilmiah telah terbukti mempunyai kemampuan antioksidatif dan aktivitas hipoglikemik (Suarsana 2009). Harnani (2009) melaporkan tepung tempe kacang komak memiliki aktivitas antioksidan yang lebih tinggi dari tepung kacang komak dengan menggunakan metode DPPH baik ekstrak air, ekstrak kloroform-metanol, dan ekstrak etil asetat. Fermentasi pada kacang komak mampu meningkatkan kapasitas antioksidan kacang komak.

Menurut penelitian Toru et al. (2000), menyatakan bahwa isoflavon bentuk aglikon diabsorbsi lebih baik bila dibandingkan dengan isoflavon bentuk glukosida. Kacang komak mengandung flavonoid, alkaloid, saponin dan tanin. Flavonoid dapat berperan dalam kerusakan jaringan pankreas yang diakibatkan oleh alkilasi DNA akibat induksi aloksan sebagai akibatnya dapat memperbaiki morfologi pankreas. Flavonoid dilaporkan memiliki aktivitas antidiabetes yang mampu meregenerasi sel pada pulau Langerhans (Shandar et al. 2011). Senyawa saponin bekerja dengan cara menurunkan absorpsi di usus dengan menurunkan penyerapan glukosa dan memodifikasi metabolisme karbohidrat, meningkatkan pemanfaatan glukosa di jaringan perifer, dan penyimpanan glikogen serta peningkatan sensitivitas reseptor insulin di jaringan. Alkaloid terbukti mempunyai kemampuan regenerasi sel $\beta$ pankreas yang rusak. Tanin diketahui dapat memacu metabolisme glukosa dan lemak sehingga timbunan kedua sumber kalori ini dalam darah dapat dihindari. Tanin mempunyai aktivitas antioksidan dan menghambat pertumbuhan tumor. Tanin juga mempunyai aktivitas hipoglikemik yaitu dengan meningkatkan glikogenesis. Selain itu, tanin juga berfungsi sebagai astringent atau pengkhelat yang dapat mengerutkan membran epitel usus halus sehingga mengurangi penyerapan sari makanan dan sebagai akibatnya menghambat asupan gula dan laju peningkatan gula darah tidak terlalu tinggi (Prameswari dan Widjanarko 2014).

Komplikasi kronik lain dari diabetes mellitus berkaitan dengan penyakit-penyakit pembuluh darah (kardiovaskular) dan biasanya diklasifikasikan menjadi penyakit pembuluh darah kecil, yang termasuk mata, ginjal dan syaraf (penyakit mikrovaskular) dan penyakit pembuluh darah besar, yang melibatkan jantung 
(penyakit makrovaskular). Penyakit-penyakit ini disebabkan oleh tingginya kadar lipid dalam darah pada penderita diabetes, yang memicu terjadinya reaksi oksidasi lipid yang akan menghasilkan radikal bebas. Radikal bebas merupakan senyawa yang sangat reaktif dan mampu menimbulkan berbagai penyakit, seperti kanker, dan aterosklerosis. Pembentukan radikal bebas dapat dihambat dan dikurangi oleh senyawa antioksidan melalui proses antioksidasi (Giri 2008).

Bahan diabetonik yang digunakan pada penelitian ini adalah aloksan monohidrat yang dapat menyebabkan stres oksidatif pada sel $\beta$, dan juga pasien yang menderita diabetes sering mengalami stres oksidatif (Widowati 2008). Menurut Istiani (2010), antioksidan pada isoflavon sangat dibutuhkan tubuh untuk menghentikan reaksi pembentukan radikal bebas, sehingga dapat menghambat proses penuaan dini, mencegah penyakit degeneratif seperti aterosklerosis, jantung koroner, diabetes melitus, dan kanker. Antioksidan dapat meningkatkan massa sel beta sehingga dapat menyimpan insulin lebih banyak untuk selanjutnya disekresikan yang berdampak pada penurunan kadar glukosa darah (Kaneto et al. 1999). Dengan demikian yoghurt kacang komak dapat digunakan sebagai obat antihiperglikemik pada penderita diabetes hiperkolesterolemia

\section{SIMPULAN}

Kesimpulan yang dapat diambil sampai tahapan ini adalah semua kelompok uji sediaan yoghurt kacang komak memiliki aktivitas dalam menurunkan kadar glukosa darah pada hamster diabetes dan hiperkolesterolemia serta kelompok uji yoghurt III dosis $10,8 \mathrm{~g} / \mathrm{kg}$ BB memiliki persentase penurunan kadar glukosa yang sebanding dengan kelompok positif yang diberikan metformin $\mathrm{HCl}$.

\section{UCAPAN TERIMA KASIH}

Ucapan terima kasih ditujukan kepada Lembaga Penelitian dan Pengembangan Universitas Muhammadiyah Prof. Dr. Hamka yang telah membiayai penelitian Internal dengan No. Kontrak : 166/F.03.07/2017.

\section{DAFTAR PUSTAKA}

Dwitiyanti, Sunaryo H, Kania IR. 2015. Uji Aktivitas Antihiperkolesterolemia Fraksi Etil Asetat Ekstrak Daun Kelor (Moringa oleifera Lam.) Terhadap Kadar
Koleterol Total dan LDL Kolesterol Pada Hamster Hiperkolesterolemia. Pharmacy. 12(2): 153-163.

Ganiswara SG. 2009. Farmakologi dan Terapi. Edisi V. Jakarta (ID): Fakultas Kedokteran Universitas Indonesia.

Giri NL. 2008. Potensi Antioksidasi Daun Salam: Kajian In Vivo Pada Tikus Hiperkolesterolemia dan Hiperglikemia [skripsi]. Bogor (ID): Institut Pertanian Bogor.

Hanafiah KA. 1993. Rancangan Percobaan Teori dan Aplikasi. Edisi 2. Jakarta (ID): Citra Niaga Rajawali. HIm. 9.

Harnani S. 2009. Studi Karakteristik dan Kapasitas Antioksidan Tepung Tempe Kacang Komak (Lablab purpureus (L.) Sweet) [skripsi]. Bogor (ID): Institut Pertanian Bogor.

Hidayat IR, Kusrahayu, Mulyani S. 2013. Total Bakteri Asam Laktat, Nilai $\mathrm{pH}$, dan Sifat Organoleptik Minuman Yoghurt dari Susu Sapi yang Diperkaya dengan Ekstrak Buah Mangga. Animal Agriculture Journal. 2(1): 160-167.

Istiani Y. 2010. Karakterisasi Senyawa Bioaktif Isoflavon dan Uji Aktivitas Antioksidan dari Ekstrak Etanol Tempe Berbahan Baku Koro Pedang (Canavalia ensiformis) [tesis]. Surakarta (ID): Universitas Sebelas Maret Surakarta.

Jannah AM, Legowo AM, Pramono YB, Al-Baari AN, Abduh SBM. 2014. Total Bakteri Asam Laktat, pH, Keasaman, Citarasa dan Kesukaan Yogurt Drink dengan Penambahan Ekstrak Buah Belimbing. Jurnal Aplikasi Teknologi Pangan.3(2): 7-11

Kaneto $\mathrm{H}$, Kajimoto $\mathrm{Y}$, Miyagawa J, Matsuoka T, Fujitani $\mathrm{Y}$, Umayahara $\mathrm{Y}$, Hanafusa $\mathrm{T}$, Matsuzawa $\mathrm{Y}$, Yamasaki Y, Hori M. 1999. Beneficial Effects of Antioxidants in Diabetes: Possible Protection of Pancreatic Beta Cells Against Glucose Toxicity. Diabetes. 48: 2398-2406.

Kante K, Reddy CS. 2013. Anti Diabetic Activity of (Dolichos lablab) (seeds) in StreptozotocinNicotinamide Induced Diabetic Rats. Journal for Drug and Medicines. 5(1): 32-40.

Keong SY, Ali HM, Yusof HM, Alitheen NB, Boon WYH, Soo PK, Kamariah L. 2012. Antihyperglicemic Effects of Fermented and Nonfermented Mung Bean Extract on Alloxan-Induced-Diabetic Mice. Journal of Biomedicine and Biotechnology. 2012: 17.

Khayrani AC. 2008. Pengaruh Konsentrat Protein Kacang Komak (Lablab purpureus (L.) Sweet)

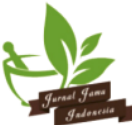


Terhadap Kadar Glukosa Darah, Profil Lipid, dan Peroksidasi Lipid Tikus Diabetes [skripsi]. Bogor (ID): Institut Pertanian Bogor.

Marcelia K. 2014. Pengaruh Pemberian Yoghurt Kacang Merah (Phaseolus vulgaris L.) terhadap Kadar Kolesterol Total pada Wanita Dislipidemia. Artikel Penelitian. Semarang (ID): Universitas Diponegoro

Nurcahyaningtyas HR. 2012. Efek Antihiperlipidemia Susu Kacang Kedelai (Glycine max (L.) Merr.) Pada Tikus Jantan yang Diberi Diit Tinggi Kolesterol dan Lemak [skripsi]. Depok (ID): Universitas Indonesia.

Prameswari OM, Widjanarko SB. 2014. Uji Efek Ekstrak Air Daun Pandan Wangi Terhadap Penurunan Kadar Glukosa Darah dan Histopatologi Tikus Diabetes Mellitus. Jurnal Pangan dan Agroindustri. 2(2): 1627.

Primawestri MA. 2014. Pengaruh Pemberian Susu Koro Pedang (Canavalia ensiformis) Terhadap Kadar Kolesterol Total dan Trigliserida Tikus Sprague Dawley Hiperkolesterolemia. Artikel Penelitian. Semarang (ID): Universitas Diponegoro.

Ray B, Bhunia A. 2008. Fundamental food microbiology. 4th ed. CRC Press. Boca Raton. HIm 492.

Salim RH. 2013. Pengaruh Yoghurt Kacang Kedelai Kuning Terhadap Kadar LDL Serum Pada Tikus Putih Jantan Galur Wistar Hiperlipidemia. Naskah Pulikasi. Tanjungpura (ID): Universitas Tanjungpura.

Santoso S. 2010. Statistik Parametrik. Jakarta (ID): Elek Media Komputindo.

Shandar HK, Kumar B, Prasher S, Tiwari P, Salhan M, Sharma P. 2011. A Review of Phytochemistry and Pharmacology of Flavonoids. Internationale Pharmaceutica Sciencia. 1(1): 25-41.

Soekarto ST. 1985. Penilaian Organoleptik. Jakarta (IDO: Bhratara Karya Aksara.

Srianta I, Trisnawati CY. 2015. Pengantar Teknologi Pengolahan Minuman. Yogyakarta (ID): Pustaka Pelajar. HIm 162-164.
[SNI]Standar Nasional Indonesia. 2009. SNI 2981:2009. Yogurt. Jakarta (ID): Badan Standardisasi Nasional (BSN). HIm 1-51

Suarsana NI, Suarini AG, Utama HI. 2004. Pengaruh Yoghurt Terhadap Kadar Kolesterol Total dan Profil Lipoprotein Serum Kelinci. Journal Veterine. 5: 1214.

Sukaryana Y, Atmomarsono U, Yunianto VD, Supriyatna E. 2011. Peningkatan Nilai Kecernaan Protein Kasar dan Lemak Kasar Produk Fermentasi Campuran Bungkil Inti Sawit dan Dedak Padi Pada Broiler. Jurnal Ilmu dan Teknologi Peternakan. 1(3):161172.

Suyatna FD. 2009. Hipolipidemik. Dalam: Gunawan SG, Setiabudy R, Nafrialdi, Elysabeth (Eds). Farmakologi dan Terapi. Edisi V. Jakarta (ID): Penerbit Buku Kedokteran EGC. HIm 373-378.

Toru I, Aiko O, Sachiko O, Aichiro T, Makato S, Mamoru K, Yoshiro K. 2000. Soy Isoflavone Aglycones Are Absorbed Faster and in Higher Amounts than Their Glucosides in Humans. The Journal of Nutrition. 130(7): 1695-1699.

Triplitt CL, Reasner CA, Isley WL. 2008. Diabetes Mellitus. Dalam: Dipiro et al. 2008. Pharmacotherapy : a Pathophysiologic approach. New York (US): Seventh ed. Mc Graw Hill. HIm. 1220

Wardani E, Wahyudi P, Dewi KR, Setiawan R. 2015. Efek Antihiperglikemik Dan Antihiperkolesterol Ekstrak Tempe Kacang Komak (Lablab Purpureus (L.) Sweet) Pada Hamster Diabetik Diet Tinggi Kolesterol. Pharmacy. 12(2): 164-175.

Widowati W. 2008. Potensi Antioksidan sebagai Antidiabetes. Jurnal Kesehatan Masyarakat. 7(2): 1-11. 